Media Publikasi Promosi Kesehatan Indonesia The Indonesian Journal of Health Promotion

\title{
Gambaran Angka Kejadian Anemia Kehamilan Pada Kunjungan Pertama Berdasarkan Umur, Gravid, Paritas, Dan Riwayat Abortus Di Puskesmas Makale Pada Bulan Februari, Maret, Dan April Tahun 2017
}

\author{
Overview of Pregnancy Anemia Rate at First Visit Based on Age, Gravid, Parity, and \\ Abortion History in Makale Health Center in February, March, and April 2017 \\ Mariany Sampe \\ Akademi Kebidanan Sinar Kasih Toraja \\ Email : marianysampeakbidsinarkasih@gmail.com
}

\begin{abstract}
Abstrak
Dampak anemia dapat menyebabkan berkurangnya daya konsentrasi, kemampuan akademik menurun, mudah merasa letih, jantung berdetak lebih cepat, warna kulit menjadi pucat, latergi, ganguan pada janin yang di kandung, menghambat pertumbuhan fisik, dampak menimbulkan resiko bayi lahir dengan berat badan yang kurang. Faktor yang menyebabkan terjadinya anemia adalah faktor lingkungan, perilaku, genetik, dan pelayanan kesehatan sendiri Penelitian ini bertujuan untuk mengetahui Gambaran Angka Kejadian Anemia Kehamilan Pada Kunjungan Pertama Berdasarkan Umur, Gravid, Paritas, Dan Riwayat Abortus Di Puskesmas Makale Pada Bulan Februari, Maret, Dan April Tahun 2017. Penelitian ini dilakukan di Puskesmas makale pada Tanggal 18 Januari 2018. Metode dalam penelitian ini adalah pengambilan data sekunder dan analisis deskriptif dengan menggunakan metode porpusive sampling yaitu sampel yang diambil berdasarkan karakteristik sesuai dengan ketentuan variabel independen ibu hamil yang memeriksa kehamilan pada kunjungan pertama (K.1) di Puskesmas Makale dengan jumlah 48 orang selama bulan Februari, Maret, dan April. dan namanya tercatat dalam buku register ANC. Dari hasil penelitian didapatkan 48 sampel yang tercatat dan ibu hamil yang anemia ada 29 orang $(60,42 \%)$ dan yang tidak anemia ada 19 orang (39,58\%). Dari kesimpulan diatas disarankan perlunya dukungan dari berbagai pihak yang terkait untuk mencari solusi dalam mencegah terjadinya anemia pada masa kehamilan
\end{abstract}

Kata Kunci: Anemia, Umur Gravid, Paritas dan riwayat abortus

\begin{abstract}
The impact of anemia can lead to reduced concentration, decreased academic ability, fatigue, faster heart beat, pale skin tone, latergi, interference with the fetus that is conceived, inhibits physical growth, the impact raises the risk of babies born with less weight. Factors that cause anemia are environmental, behavioral, genetic, and self-health services. This study aims to determine the description of pregnancy anemia at the first visit based on age, age, parity, and history of abortion at the Makale health center in February, March, and April Year 2017. This research was conducted at the Makale Health Center on January 18, 2018. The method in this study was secondary data collection and descriptive analysis using the porous sampling method, ie samples taken based on characteristics in accordance with the independent variable of pregnant women who examined pregnancy on the visit first (K.1) at the Makale Health Center with a total of 48 people during February, March and April. and the name is recorded in the ANC register. From the results of the study, 48 samples were recorded and pregnant women with anemia were 29 people (60.42\%) and those without anemia there were 19 people (39.58\%). From the above conclusions, it is suggested that there is a need for support from various parties involved to find solutions to prevent the occurrence of anemia during pregnancy
\end{abstract}

Keywords: Anemia, Age Gravid, Parity and history of abortion 


\section{PENDAHULUAN}

Anemia dalam kehamilan adalah kondisi ibu dengan kadar hemoglobin kurang dari 11,0 g/dL pada trimester I dan III, atau kadar hemoglobin kurang dari 11,5 g/dL pada trimester II [1]. Dampak anemia dapat menyebabkan berkurangnya daya konsentrasi, kemampuan akademik menurun, mudah merasa letih, jantung berdetak lebih cepat, warna kulit menjadi pucat, latergi, ganguan pada janin yang di kandung, menghambat pertumbuhan fisik, dampak menimbulkanresiko bayi lahir dengan berat badan yang kurang. Faktor yang menyebabkan terjadinya anemia adalah faktor lingkungan, perilaku, genetik, dan pelayanan kesehatan sendiri [2].

Menurut World Health Organization (WHO) 2014, Angka Kematian Ibu (AKI) di dunia yaitu 289.000 jiwa. Afrika sub sahar 179.000 jiwa, dan Asia Tenggara 6.000 jiwa. Angka Kematian Ibu di Negara-Negara Asia Tenggara yaitu Indonesia 190 per 100.000 kelahiran hidup. Filipina 170 per 100.000 kelahiran hidup,Vietnam 49 per 100.000 kelahiran hidup, Thailand 26 per 100.000 kelahiran hidup, Brunei 27 per 100.000 kelahiran hidup, dan Malaysia 39 per 100.000 kelahiran hidup [3]

Data Angka Kematian Ibu (AKI) Tahun 2015 berdasarkan hasil survey penduduk antar sensus (SUPAS) jumlah Angka Kematian Ibu (AKI) yaitu 305 kematian ibu per 100.000 kelahiran hidup [3].

Jumlah angka kematian ibu di Sulawesi Selatan pada Tahun 2014 jumlah 138 orang atau 93,20 per 100.000 kelahiran hidup terdiri dari kematian ibu hamil 15 orang $(10,86 \%)$ kematian ibu bersalin 54 orang $(39,13 \%)$ kematian ibu nifas 69 orang (50,00\%). Adapun kematian ibu merut umur yaitu < 20 Tahun sebanyak 14 oarng, umur 20-34 Tahun sebanyak 87 orang, dan $\geq 35$ Tahun sebanyak 37 orang [3].

Berdasarkan data anemia ibu hamil dari dinas kesehatan kabupaten Tana Toraja jumlah ibu hamil pada tahun 2017 sebanyak 4.119 orang dan alasan saya mengambil judul ini karena masih tingginya angka kejadian anemia pada ibu hamil untuk itu perlu dilakukan penelitian untuk mengetahui penyebab terjadinya anemia sebagai acuan perbaikan dan pencegahan terjadinya anemia pada ibu hamil di kemudian hari.

\section{METODE}

Jenis penelitian menggunakan Pendekatan Deskriptif yang bertujuan untuk memperoleh Gambaran Kejadian Anemia Kehamilan Pada Kunjungan Pertama Berdasarkan Umur, Gravid, Paritas dan Riwayat Abortus di Puskesmas Makale Tahun 2017. Populasi pada penelitian ini adalah semua ibu hamil yang datang berkunjung di Puskesmas Makale Kabupaten Tana Toraja pada bulan Februari, Maret dan April Tahun 2017 sebanyak 48 orang dan sampel dalam penelitian ini adalah ibu hamil yang datang di Puskesmas makale sebanyak 48 orang dan namanya tercatat di buku register ANC.

\section{HASIL}

Hasil penelitian yang selengkapnya akan disajikan dalam bentuk tabel disertai penjelasan dari masing-masing tabel:

1. Kejadian Anemia Berdasarkan Umur

Tabel 1. Distribusi Berdasarkan Kejadian Anemia Pada Kunjungan Pertama Berdasarkan Umur di Puskesmas Makale Pada Bulan Februari, Maret dan April Tahun 2017 


\begin{tabular}{lccc}
\hline \multirow{2}{*}{ Variabel } & Ibu Hamil & $\begin{array}{c}\text { Ibu Hamil yang } \\
\text { Anemia }\end{array}$ & \multirow{2}{*}{ \% } \\
\cline { 2 - 4 } & $\mathbf{n}$ & $\mathbf{n}$ & \\
\hline Umur & & & \\
\hline Resiko tinggi & 11 & 7 & $63,64 \%$ \\
\hline Resiko rendah & 37 & 22 & $59,46 \%$ \\
\hline Jumlah & 48 & 29 & \\
\hline
\end{tabular}

Sumber : Data Sekunder, 2017

Berdasarkan table 1 Dari 48 sampel ibu hamil yang tercatat ada 29 ibu hamil yang anemia. Ibu hamil dengan resiko tinggi ada 11 orang dan yang anemia ada 7 orang (63,64\%), sedangkan ibu hamil dengan resiko rendah ada 37 orang dan yang anemia ada 22 orang $(59,46 \%)$.

2. Kejadian Anemia Berdasarkan Gravid

Tabel 2. Distribusi Berdasarkan Kejadian Anemia Pada Kunjungan Pertama Berdasarkan Gravid di Puskesmas Makale Pada Bulan Februari, Maret dan April Tahun 2017

\begin{tabular}{cccc}
\hline \multirow{2}{*}{ Variabel } & Ibu Hamil & $\begin{array}{c}\text { Ibu Hamil yang } \\
\text { Anemia }\end{array}$ & \multirow{2}{*}{$\%$} \\
\cline { 2 - 3 } & $\mathbf{n}$ & $\mathbf{n}$ & \\
\hline Gravid & & & \\
\hline Primigravida & 19 & 12 & $63,16 \%$ \\
\hline Multigravida & 21 & 14 & $66,67 \%$ \\
\hline Grandmultigravida & 8 & 3 & $37,5 \%$ \\
\hline Jumlah & 48 & 29 & \\
\hline
\end{tabular}

Sumber : Data Sekunder, 2017

Berdasarkan table 2 Dari 48 sampel ibu hamil yang tercatat ada 29 ibu hamil yang anemia. tercatat ibu hamil primigravida ada 19 orang dan yang anemia ada 12 orang $(63,16 \%)$, ibu hamil multigravida ada 21 orang dan yang anemia ada 14 orang $(66,67 \%)$, sedangkan ibu hamil grandmultigravida ada 8 orang dan yang anemia ada 3 orang $(37,5 \%)$.

3. Kejadian Anemia Berdasarkan Paritas

Tabel 3. Distribusi Berdasarkan Kejadian Anemia Pada Kunjungan Pertama Berdasarkan Paritas di Puskesmas Makale Pada Bulan Februari, Maret dan April Tahun 2017

\begin{tabular}{lccc}
\hline \multirow{2}{*}{ Variabel } & Ibu Hamil & $\begin{array}{c}\text { Ibu Hamil yang } \\
\text { Anemia }\end{array}$ & \multirow{2}{*}{$\%$} \\
\cline { 2 - 3 } & $\mathbf{n}$ & $\mathbf{n}$ & \\
\hline Paritas & & & \\
\hline Nulipara & 20 & 13 & $65 \%$ \\
\hline Primipara & 12 & 6 & $50 \%$ \\
\hline Multipara & 13 & 9 & $69,23 \%$ \\
\hline Grandmultipara & 3 & 1 & $33,33 \%$ \\
\hline Jumlah & 48 & 29 & \\
\hline
\end{tabular}

Sumber : Data Sekunder, 2017

Berdasarkan table 3 Dari 48 sampel ibu hamil yang tercatat ada 29 ibu hamil yang anemia. Nulipara ada 
20 orang dan yang anemia ada 13 orang (65\%), primipara ada 12 orang dan yang anemia ada 6 orang (50\%), multipara ada 13 orang dan yang anemia 9 orang $(69,23 \%)$ sedangkan grandmultipara ada 3 orang dan yang anemia ada 1 orang $(33,33 \%)$.

4. Kejadian Anemia Bedasarkan Riwayat Abortus

Tabel 4. Distribusi Berdasarkan Kejadian Anemia Pada Kunjungan Pertama Berdasarkan Riwayat Abortus di Puskesmas Makale Pada Bulan Februari, Maret dan April Tahun 2017

\begin{tabular}{lccc}
\hline \multirow{2}{*}{ Variabel } & Ibu Hamil & $\begin{array}{c}\text { Ibu Hamil yang } \\
\text { Anemia }\end{array}$ & \multirow{2}{*}{$\mathbf{0}$} \\
\cline { 2 - 3 } & $\mathbf{n}$ & $\mathbf{n}$ & \\
\hline Riwayat Abortus & & & $50 \%$ \\
\hline Ya & 4 & 2 & $61,36 \%$ \\
\hline Tidak & 44 & 27 & \\
\hline Jumlah & 48 & 29 & \\
\hline
\end{tabular}

Sumber : Data Sekunder, 2017

Berdasarkan table 4 Dari 48 sampel ibu hamil yang tercatat ada 29 ibu hamil yang anemia yang ada riwayat abortus ada 4 orang dan yang anemia ada 2 orang (50\%), sedangkan yang tidak ada riwayat abortus ada 44 orang dan yang anemia 27 orang $(61,36 \%)$.

\section{PEMBAHASAN}

1. Kejadian Anemia Berdasarkan Umur

Umur diartikan dengan lamanya keberadaan seseorang diukur dalam satuan waktu di pandang dari segi kronologik, individu normal yang memperlihatkan derajat perkembangan anatomis dan fisiologik sama Semakin cukup umur maka tingkat kematangan dan kekuatan seseorang akan lebih matang dalam berfikir dan bekerja [4].

Berdasarkan penjelasan pada Bab II bahwa ibu dikatakan berisiko tinggi terjadinya anemia apabila ibu hamil berusia dibawa 20 tahun dan diatas 35 tahun (resiko tinggi) Terjadi kesamaan antara teori yg di ungkapkan pada bab II dan hasil penelitian karena pada penelitian ini terbukti bahwa lebih banyak ibu dengan resiko tinggi yang mengalami anemia yaitu $(63,64 \%)$.

2. Kejadian Anemia Berdasarkan Gravid

Gravida adalah jumlah kehamilan. Seorang ibu yang sering hamil mempunyai resiko mengalami anemia pada kehamilan berikutnya apabila tidak memperhatikan kebutuhan nutrisi. Adapun seorang ibu yang hamil pertama kali berisiko pula karena belum mengalami pengalaman sehingga berdampak pada perilaku yang berkaitan dengan asupan nutrisi [5].

Namun peningkatan resiko untuk menderita anemia antara primigravida dan multigravida relatif kecil dan secara statistic tidak bermakna sedangkan untuk grandmultigravida memiliki resiko lebih tinggi untuk menderita anemia.

Terjadi kesenjangan antara teori yg di ungkapkan dan hasil penelitian karena pada penelitian ini terbukti bahwa lebih banyak ibu dengan multigravida yang mengalami anemia yaitu 66,67 \%. Sedangkan pada teori yang berisiko yaitu grandmultigravida , kemungkinan ini disebabkan karena ibu grandmultigravida lebih berpengalaman mengenai asupan gizi selama kehamilannya. 
3. Kejadian Anemia Berdasarkan Paritas

Paritas adalah jumlah kehamilan yang diakhiri dengan kelahiran janin yang memenuhi syarat untuk melangsungkan kehidupan. Paritas adalah banyaknya bayi yang dilahirkan seorang wanita/ibu dalam keadaan hidup maupun lahir mati.

Terjadi kesenjangan antara teori dengan hasil penelitian karena pada penelitian ini terbukti bahwa lebih banyak ibu multipara yang mengalami anemia yaitu 69,23\%. Kemungkinan penyebabnya adalah kurangnya perhatian ibu hamil terhadap kehamilannya, kemungkinan pula karena faktor ekonomi.

4. Kejadian Anemia Berdasarkan Riwayat Abortus

Abortus adalah berakhirnya suatu kehamilan oleh akibat-akibat tertentu pada atau sebelum kehamilan tersebut berusia 22 minggu. Anemia dapat mengurangi suplay oksigen pada metabolisme ibu karena kekurangan kadar haemoglobin untuk mengikat oksigen yang dapat mengakibatkan efek tidak langsung pada ibu dan janin antara lain terjadinya abortus selain itu lebih rentang terhadap infeksi dan kemungkinan bayi lahir premature.

Terjadi kesenjangan antara teori yang di ungkapkan hasil penelitian karena pada penelitian ini terbukti bahwa lebih banyak ibu yang tidak abortus mengalami anemia yaitu 61,36 \%.

\section{KESIMPULAN DAN SARAN}

Dari hasil penelitian di dapatkan lebih banyak ibu dengan resiko tinggi yang mengalami anemia yaitu 63,64 \% kemungkinan di sebabkan karena wanita hamil mudah mengalami guncangan mental yang mengakibatkan kurangnya perhatian terhadap pemenuhan kebutuhan zat - zat gizi selama kehamilannya. Sedangkan kehamilan dengan usia di atas 35 tahun pun akan rentan terhadap anemia. Hal ini terkait dengan penurunan daya tahan tubuh sehingga mudah terkena berbagai infeksi selama kehamilan, di dapatkan lebih banyak ibu dengan multigravida yang mengalami anemia yaitu 66,67\% kemungkinan di sebabkan karena kurang memperhatikan asupan nutrisi selama kehamilannya. di dapatkan lebih banyak ibu dengan multipara yaitu 69,23\% kemungkinan di sebabkan karena faktor ekonomi atau kurang memperhatikan giznya. di dapatkan lebih banyak ibu yang tidak ada riwayat abortus yang anemia berarti tidak ada hubungan antara riwayat abortus dengan anemia.

Diharapkan khususnya bidan diharapakan dapat mengetahui tanda - tanda bahaya pada kehamilan sehingga dapat dideteksi lebih awal apabila menemukan salah satu tanda bahaya pada kehamilan seperti anemia dalam kehamilan. Diharapkan kepada petugas kesehatan meningkatkan penyuluhaan tentang Antenatal Care dan memotivasi ibu dalam mempertahankan kesehatan dan kehamilannya melalui pemanfaatan pelayanan Antenatal care yang maksimal pada pelayanan kesehatan yang telah ada.

\section{DAFTAR PUSTAKA}

[1] F. Ernawati, Y. Rosamalina, and Y. Permanasari, "Pengaruh Asupan Protein Ibu Hamil Dan Panjang Badan Bayi Lahir Terhadap Kejadian Stunting Pada Anak Usia 12 Bulan Di Kabupaten Bogor (Effect of the Pregnant Women's Protein Intake and Their Baby Length at Birth to the Incidence of Stunting Among Children," Nutr. Food Res., vol. 36, no. 1, pp. 1-11, 2013.

[2] I. B. G. Manuaba, "Ilmu kebidanan, penyakit kandungan \& keluarga berencana untuk pendidikan bidan," 1998.

[3] N. Sulistiyowati, P. S. Hidayangsih, and D. H. Tjandrarini, "Kesinambungan Pemanfaatan Pelayanan Kesehatan Maternal di Indonesia," Indones. Bull. Heal. Res., vol. 45, no. 3, pp. 177-186, 2017.

[4] S. T. Maulia and I. Januarti, "PENGARUH USIA, PENGALAMAN, DAN PENDIDIKAN DEWAN KOMISARIS TERHADAP KUALITAS LAPORAN KEUANGAN (Studi empiris pada perusahaan real estate dan property yang go public di Bursa Efek Indonesia tahun 2010-2012)." Fakultas Ekonomika dan Bisnis, 2014. 
[5] N. Nasyidah, "Hubungan Anemia dan Karakteristik Ibu Hamil di Puskesmas Alianyang Pontianak," J. Mhs. PSPD FK Univ. Tanjungpura, vol. 1, no. 1, 2011. 